\title{
Perjalanan Haji Indonesia di Masa Kolonial
}

\author{
Dawam Multazamy Rohmatulloh \\ Institut Agama Islam Sunan Giri (INSURI) Ponorogo \\ dmnusantara@gmail.com
}

\begin{abstract}
Abstrak
Hajj or pilgrimage is one of the important worship activities for Indonesian Muslims since past. Based on colonial archives, this paper describes the dynamics of the pilgrimage of Indonesia in the colonial period. The long duration of the trip, a tough challenge, and the high cost of travel is a "fee" to be paid by the pilgrims in the past. Moreover, the existence of many service provider of the pilgrimage also influence that dynamics. On the other hand, the colonial government also plays an important role by issuing a variety of regulations to ensure the "order" of the pilgrimage.
\end{abstract}

Keywords: Hajj trip, company, regulation, colonial period.

\section{Pendahuluan}

Pelaksanaan ibadah haji oleh umat Islam dari Indonesia memiliki potret peristiwa sejarah yang sangat panjang. Kumpulan potret tersebut merupakan hal yang menarik, selain karena fakta ibadah haji itu sendiri, juga karena pelaksanaan ibadah haji di Indonesia merupakan isu yang sangat penting mengingat Indonesia merupakan negara dengan jumlah penganut agama Islam terbesar di dunia. Dari masa ke masa, jumlah warga negara Indonesia - yang juga termasuk pada lima besar negara dengan populasi penduduk terbanyak di dunia, yang berangkat menjalankan ibadahhaji ke Tanah Suci Makkah selalu lebih banyak dari masing-masing negara lainnya. Potret pelaksanaan ibadah haji oleh masyarakat Indonesia tidak baru saja dimulai ketika Indonesia merdeka,

Penulis adalah dosen tetap Fakultas Dakwah IAI Sunan Giri Ponorogo 
melainkan sudah sangat lama. Meskipun gambaran tersebut dapat pula dilacak dari folklor yang mengisahkan tentang perjalanan haji umat Islam dari Nusantara sejak masa Walisanga (abad ke-15 hingga abad ke-17), namun sumber kearsipan yang cukup komprehensiftercatat sekurang-kurangnya sejak dua abad silam di masa kolonial.

Bisa dibayangkan bagaimana proses perjalanan nenek moyang bangsa ini dalam menempuh jarak yang sangat jauh dari kepulauan Nusantara hingga ke Tanah Hijaz, karena pada masa itu satu-satunya moda transportasi yang memungkinkan adalah jalur laut. Menggunakan kapal layar yang dikelola oleh maskapai-maskapai transportasi, perjalanan berlangsung hingga memakan waktu lima bulan karena hanya mengandalkan tiupan angin laut. Baru di akhir abad ke-19, ketika teknologi kapal uap sudah digunakan, durasi perjalanan dapat menjadi lebih cepat.2 Durasi perjalanan yang panjang dan ditambah dengan masih sederhananya alat transportasi menjadikan perjalanan haji di masa lampau sangat berat.Namun beratnya perjalanan yang harus ditempuh itu tidak menyurutkan gairah masyarakat untuk menunaikan ibadah rukun islam kelima tersebut, yang ditandai dengan jumlah pejalannya yang selalu dan semakin banyak.

Berangkat dari latar belakang di atas, penulis tertarik untuk mengkaji hal berikut:pertama,dinamikaperjalananibadah haji Indonesia pada masa kolonial, dan kedua, keterlibatanmaskapai penyedia jasa perjalanan.

\section{Potret Perjalanan Ibadah Haji di Masa Kolonial}

Perjalanan haji sudah lama dijalani oleh masyarakat Islam di Indonesia. Keterpanggilan masyarakat Islam di Indonesia untuk berangkat haji ini selain karena dorongan ruhaniyyah atau motivasi keagamaan, juga karena maraknya perkembangan pelayaran yang ada. Sebagaimana dicatat bahwa teknologi pelayaran di kerajaan-kerajaan maritim pada saat itu sudah cukup pesat. Kedatangan pedagang muslim beserta pendakwah yang berkelindan di perairan Nusantara tidak hanya menarik masyarakat pribumi untuk masuk agama Islam, tetapi juga semakin meningkatkan keinginan mereka untuk pergi berhaji.

M. Dien Majid, Berhaji di Masa Kolonial (Jakarta: CV. Sejahtera, 2008), h. 2 
Bahkan ada anggapan di tengah masyarakat bahwa orang yang sudah pernah berhaji adalah muslim yang lebih alim atau baik (hoe verder van Mekka, hoe beter moslim).3Dengan kata lain, pengalaman berhaji dapat menentukan kadar keislaman seseorang.

Sebelum dikenalnya teknologi uap dan motor yang kemudian memungkinkan perjalanan haji dengan kapal api atau motor pada akhir abad 19, para jama'ah memanfaatkan kapal layar - yang sejatinya merupakan kapal dagang, untuk perjalanan haji.Dengan hanya mengandalkan kekuatan tiupan angin laut, maka perjalanan dari Nusantara hingga ke pelabuhan Aden membutuhkan waktu tak kurang dari lima bulan.4

Fasilitas yang diperoleh dalam kapal pun sangat jauh dari nyaman. Penumpang berdesak-desakan dalam dek dan lorong kapal beserta dengan barang bawaan mereka. Dengan pembagian tempat yang sangat terbatas tersebut, tempat untuk shalat yang longgar pun tidak memungkinkan. Bahkan untuk keperluan buang hajat besar dan kecil pun dilakukan di tempat mereka duduk. Ditambah lagi untuk keperluan makan yang harus diurus sendiri oleh penumpang, dan beragam kekurangan lainnya.5

Kondisi yang menyedihkan tersebut diperparah pula dengan sikap oknum nakhoda dan awak kapal yang kadangkala bertindak licik ataupun jahat pada penumpangnya. Ada sebuah laporan yang menyebutkan bagaimana nakhoda yang jahat sampai membuang barang milik penumpang ke laut, bahkan hingga timbul perkelahian antara penumpang dengan awak kapal.Tak hanya itu, ada pula kesulitan-kesulitan alam yang datang sepanjang perjalanan.Dalam sebuah laporan kolonial pada tahun 1893, ada badai besar yang menyerang sebuah pelgrimschip (kapal haji) yang tidak laik jalan dalam perjalanan pulang

\footnotetext{
3 J. Eisenberger, Indie en de Bedevaart naar Mekka (Leiden: M. Dubbeldeman, 1928), h. 2

4

Martin van Bruinessen, Kitab Kuning Pesantren dan Tarekat Tradisi-Tradisi Islam di Indonesia (Bandung: Mizan, 1995), h. 48

Kondisi yang memprihatinkan ini memang bukanlah kondisi secara umum, hanya pada kasus tertentu di mana terjadi penyelewengan oleh perusahaan penyelenggara perjalanan Haji. Selengkapnya lihat dalam Arsip Nasional RI, TGs tanggal November 1896 No. 353 Geh.
} 
dari Tanah Suci dan mengakibatkan seratusan jama'ah meninggal dan puluhan peti perbekalan hanyut.6

Tantangan alam berupa wabah penyakit juga menjadi tantangan bagi para jama'ah. Penyebaran wabah penyakit dimungkinkan terjadi karena terpusatnya kumpulan ribuan manusia dari aneka latar belakang dalam satu tempat, sehingga jika ada satu saja orang yang membawa virus menular maka penularannya bisa cepat menyebar. Sebagai contoh ketika terjadi wabah kolera yang terjadi tiga belas kali dalam kurun waktu tahun 1860-1902,7 pes di tahun 1898, 8 dan cacar di tahun 1927.9

Aneka ragam kesulitan tersebut nyatanya tidak mengurangi minat masyarakat untuk pergi berhaji. Hal ini terbukti dengan tren jumlah jama'ah haji yang meskipun fluktuatif namun relatif stabil tiap tahunnya, bahkan cenderung meningkat - kecuali pada beberapa tahun tertentu. Berikut tabel jumlah jama'ahhaji dari Nusantara dalam beberapa tahun yang diambil secara acak: 10

\begin{tabular}{|c|c|}
\hline Tahun Masehi & Jumlah Jama'ah Haji \\
\hline 1850 & 7411 \\
\hline 1855 & 1668 \\
\hline 1879 & 5331 \\
\hline 1880 & 9542 \\
\hline 1886 & 2524 \\
\hline 1890 & 5076 \\
\hline
\end{tabular}

\footnotetext{
6 Musibah dalam Kapal Samoa ini berkaitan erat dengan penyelewengan yang dilakukan oleh perusahaan penyelenggara perjalanan Haji, selengkapnya lihat dalam Arsip Nasional RI, Mgs. 4-11-1893 no. 2811, G.B. Agenda 2280/1895 sebagaimana dikutip Dien, Berhaji, h. 142.

8 Lihat Jan Hendrik Ziesel, De Pelgrime-Quarantaine, yang dikutip dalam Dien, Berhaji, h. 112.

Lihat Rahmat Taufiq Hidayat dkk, Almanak Alam Islami Sumber Rujukan Keluarga Muslim Milenium Baru, $_{9}$ yang dikutip dalam Dien, Berhaji, h. 117. 115.

Lihat Abdoel Fatah, Consulaatsarts te Jeddah, Medisch Rapport 1927 yang dikutip dalam Dien, Berhaji, h.

10 bisa didapati di Arsip Nasional RI, sebagaimana dikutip juga dalam beberapa buku, di antaranya lihat dalam Dien Madjid, Berhaji dan M. Shaleh Putuhena, Historiografi Haji Indonesia, (Yogyakarta: LKiS, 2007).

11

Dien, Berhaji, h. 95
} 


\begin{tabular}{|c|c|}
\hline 1893 & $\begin{array}{c}5193 \text { atau } 8092 \text { atau } \\
13856_{12}\end{array}$ \\
\hline 1896 & 11788 \\
\hline 1899 & 7694 \\
\hline $1900 / 1901$ & 7421 \\
\hline $1901 / 1902$ & 6092 \\
\hline $1902 / 1903$ & 5679 \\
\hline $1903 / 1904$ & 9481 \\
\hline $1904 / 1905$ & 4964 \\
\hline $1908 / 1909$ & 10300 \\
\hline $1911 / 1912$ & 18353 \\
\hline $1913 / 1914$ & 28427 \\
\hline
\end{tabular}

Ada beberapa perbedaanjumlah dalam data yang diambil, seperti pada tahun 1893, disebabkan adanya perbedaan dalam sumber data utama (arsip pemerintah kolonial). Sebagai ilustrasi, dalam salah satu arsip, pemerintah kolonial menyebutkan suatu jumlah jama'ah yang berangkat dari embarkasi Onrust - misalnya. Dan dalam arsip yang lain dari tahun yang sama, pemerintah kolonial menyebutkan jumlah jama'ah yang berbeda, karena yang digunakan adalah data jama'ah dari embarkasi selain Onrust. Berdasarkan jumlah jama'ah yang banyak tersebut, dapat diambil kesimpulan bahwa jumlah jama'ah haji dari Nusantara pada masa dahulu tidaklah sedikit. Hal ini merupakan hal yang cukup mencengangkan, mengingat sulitnya perjalanan haji pada masa itu jika dibandingkan dengan masa sekarang.

Motivasi para jama'ah haji yang berangkat ke Tanah Suci pun beragam, namun berdasarkan penelitian yang dilakukan oleh Hurgronje, didapati beberapa alasan yang mendorong para jama'ah:13

\footnotetext{
Dien, Berhaji, h. 129

13

C. Snouck Hurgronje, Kumpulan Karangan Snouck Hurgronje IX (Jakarta: INIS, 1994), h. 164. Lihat juga dalam E. Gobee dan C. Adriaanse, Nasihat-Nasihat C. Snouck Hurgronje semasa Kepegawaiannya Kepada Pemerintah Hindia Belanda 1889-1936 Seri VIII (Jakarta: INIS, 1993), h. 1398
} 
1. Menjalankan perintah agama

Alasan yang normatif ini merupakan alasan utama dan paling bisa diterima, di antaranya berdasarkan dalil-dalil dalam al-Qur'an (QS. Ali Imran 97) maupun Hadits (di antaranya Riwayat Ahmad dan Muslim dari Abu Hurairah).

2. Keinginan untuk memperluas agama

Di antara jama'ah yang berangkat haji, memang tidak sedikit yang bertujuan untuk belajar ilmu-ilmu agama di Tanah Suci.

3. Status sosial

Di kalangan masyarakat, orang yang sudah pernah berhaji akan mendapatkan gelar -Hajil. Selain itu, orang tersebut juga akan mendapatkan apresiasi tinggi (lebih dihormati) di tengah masyarakat. Oleh karena itu, tidak sedikit pula jama'ah yang bertujuan untuk motif ini.

4. Kekecewaan/kejenuhan pada kehidupan di tanah air (yang masih terjajah) dan ingin terus tinggal di Mekah

Alasan ini merupakan alasan yang bisa diterima, mengingat pada saat itu adalah masa kolonial di mana segala urusan yang terkait dengan pemerintah Belanda cenderung menyusahkan masyarakat pribumi. Oleh karena itu, di antara jama'ah ada yang ingin menjadikan perjalanan haji sebagai pelarian dari kondisi di tanah air dan ingin tinggal di Mekah hingga akhir hayatnya.

Di antara empat alasan utama tadi, alasan kedua dan keempat bisa menjadi jawaban atas fakta yang kemudian ditemukan oleh Hurgronje, 14 bahwa dalam Indisch Staatsblad (lembaran negara) tahun 1859 no. 42, bahwa pada tahun 1859 saja ada 12.985 yang berangkat selama enam tahun (1852-1856), hanya ada 5.594 orang yang sudah pulang. Sisanya ada yang masih bertahan tinggal di Mekah ataupun masih dalam perjalanan pulang.Pernyataan lain juga datang dari pejabat Bupati Pasuruan yang menyatakan -sebagian besar jama'ah haji tidak kembali ke tanah air\| dalam nota bertanggal 13 Juli 1897 nomor 332/2 Rahasia, serta nota

\footnotetext{
Hurgronje, Karangan, h. 163
} 
tanggal 4 September 1897 nomor 419/2 Rahasia yang menyatakan perbandingan jumlah orang yang berangkat dan pulang haji yang berbeda drastis.15 Dari fakta ini, bisa didapati kesimpulan bahwa rombongan yang kembali ke tanah air selalu jauh lebih sedikit daripada ketika rombongan tersebut berangkat.

\section{Perusahaan Perhajian Indonesia di Masa Kolonial}

Sebelum adanya regulasi yang diterbitkan oleh pemerintah kolonial, para jama'ah haji menumpang kapal pedagang yang berlayar sepanjang Samudera Hindia. Dalam kelompok kecil, mereka mengikuti perjalanan yang ditempuh oleh kapal pedagang tersebut dari Singapura, Aceh, India, dan seterusnya.Perjalanan haji dari Jakarta, Singapura, Aceh, atau Padang ke Mekah memakan jarak geografis $\pm 8000 \mathrm{~km}, 16$ sedangkan pada masa itu satusatunya moda transportasi adalah melalui jalur laut, oleh karena itu banyaknya jama'ah haji merupakan pekerjaan besar sekaligus peluang ekonomis bagi perusahaan yang memiliki kapal.

Seiring dengan makin ramainya perjalanan haji, pemerintah kolonial pun mengeluarkan beragam regulasi yang mengatur perjalanan haji mulai dari urusan administrasi hingga transportasi. Regulasi -regulasi yang diterbitkan oleh pemerintah kolonial tersebut memuat peraturan administrasi, transportasi, pembiayaan, kesehatan, hingga monitoring ideologi jama'ah pasca ibadah haji. Regulasi dalam bentukresolutieataupun ordonantie tersebut pertama kali terbit pada 1825 , selanjutnya berturut-turut tahun $1827,1830,1831,1850,1859$, 1872, dan terakhir tahun 1922.

Awalnya, pemerintah kolonial mengelola sendiri urusan transportasi jama'ah dengan menunjuk tiga perusahaan (Rotterdamsche Lloyd, Nederland/Amsterdamsche Lloyd, dan Oceaan) untuk mengangkut jama'ah.17 Dengan menggunakan tiga perusahaan yang tergabung dalam Kongsi Tiga ini, pemerintah kolonial dimudahkan untuk mengelola

16

Gobee, Nasihat, h. 1416.

Berdasarkan perhitungan aplikasi web-based www.distancefromto.net, diakses pada 1 September 2016.

17

Dien, Berhaji, h. 116 
sekaligus memantau pelaksanaan transportasi yang diselenggarakan oleh tiga perusahaan tersebut.

Di antara kapal-kapal yang dimiliki oleh Rotterdamschemenggunakan nama-nama daerah di Indonesia, di antaranya adalah Sitoebondo, Soekaboemi, Ternate, Tapanoeli, dan Medan. Begitu juga kapal-kapal yang dimiliki oleh Nederland, di antaranya adalah Karimoen, Soemba, Kangean, Krakatau, dan Rondo. Berbeda dengan kapal-kapal Oceaan yang menggunakan nama-nama Yunani seperti Phrontis, Peisanders, Polydorus, Ixion, dan Eurymedon.18

Pemerintah kolonial juga memperbaharui regulasinya dengan menerbitkan peraturan-peraturan baru yang relevan. Di antaranya adalah aturan bahwa jama'ah harus memiliki tiket pergi- pulang(retourbiljet) sehingga bisa mengurangi kemungkinan kehabisan bekal dan tertinggal di Mekah. Adapun jama'ah yang berkeinginan untuk tinggal lebih lama di Tanah Suci, bisa menukarkan tiket pulang ke Konsulat Jenderal Hindia Belanda di Jeddah.

Dalam perkembangannya,karena tiap tahun jumlah jama'ah semakin bertambah, Kongsi Tiga tidak bisa lagi menampung penumpang yang ingin berangkat ke Tanah Suci. Hingga akhirnya pada tahun 1890-an,pemerintah kolonial memberikan kesempatan pada perusahaan lain untuk menjadi perusahaan pengangkut jama'ah haji. Belakangan, kebebasan yang diberikan pada perusahaan swasta ini ternyata berdampak negatif karena beberapa di antara mereka justru memanfaatkan kesempatan ini untuk motif keuntungan semata. 19

Sejak dibukanya keran bebas jasa penyelenggara perjalanan ibadah haji itu, lahir dan menjamurlah perusahaan- perusahaan swasta yang juga turut berperan dalam pengangkutan jama'ah. Di antara perusahaan-perusahaan swasta itu adalah Borneo Company Ltd, De Lloyd, Firma Gellatly Henkey Sewell \& Co, Firma Aliste, Jawa \& Co, Firma Knowles \& Co, dan Firma Assegaff \& Co.20 
Di tengah persaingan bebas antar perusahaan tersebut, pemerintah kolonial juga terus memperbaharui regulasi yang melindungi jama'ah. Di antaranya adalah peraturan tentang spesifikasi minimal kapal yang digunakan dan standar kualitas layanan pada penumpang. Namun demikian, tidak semua perusahaan dapat memenuhi peraturan tersebut, sehingga pemerintah kolonial juga memberlakukan denda atau sanksi bagi perusahaan atau kapal yang melanggar.21

Sebagai perbandingan, ada perbedaan-perbedaan yang sangat signifikan antara satu kapal dengan kapal perusahaan yang lain, bahkan dalam perusahaan yang sama. Di antara perbedaan antara Kapal Jawa dengan Kapal Singapura adalah sebagai berikut:22

a. Penumpang Kapal Jawa mendapatkan makan secara gratis, baik semasa dalam perjalanan maupun di karantina

b. Penumpang Kapal Jawa hanya boleh menyalakan api (untuk memasak) di atas dek ataupun dapur kapal pada waktu-waktu tertentu

c. Penumpang Kapal Singapura hanya mendapatkan bahan makanan untuk dimasak sendiri, terdiri dari ikan kering $0,1 \mathrm{~kg}$, telur asin 1 butir, sayur kering 0,002 kg, kacang hijau 0,05 kg, beras 0,5 kg, kecap 0,007 liter, cabe kering 0,01 kg, bawang kering 0,03 kg, minyak kelapa segar 0,01 liter, cuka 0,01 liter, garam $0,01 \mathrm{~kg}$, kopi $0,015 \mathrm{~kg}$, teh $0,004 \mathrm{~kg}$, gula jawa $0,004 \mathrm{~kg}$, gula pasir $0,03 \mathrm{~kg}$, dan air minum 5 liter.

d. Penumpang Kapal Singapura boleh memasak sendiri di atas dek kapal dengan kayu bakar tanpa ada batasan waktu.

Dan untuk menarik calon jama'ah lebih luas, perusahaan-perusahaan tersebut menyebar brosur yang menjelaskan fasilitas yang diperoleh. Di antara brosur yang dibagikan sebagai media promosi adalah brosur dari perusahaan Nederland pada tahun 1896 yang berisi fasilitas sebagai berikut:23

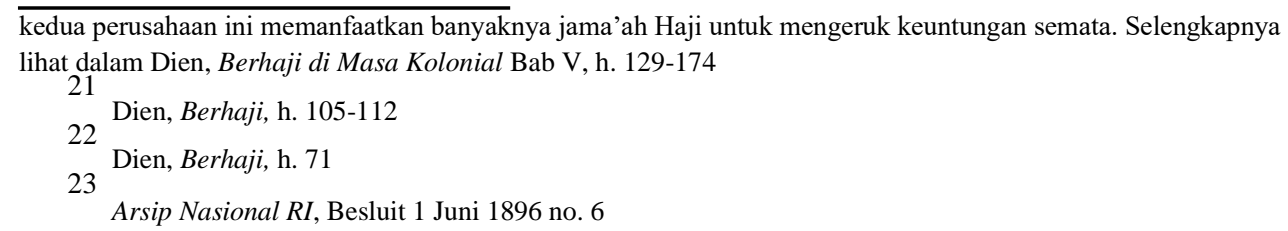


1. Makanan

Untuk penumpang Timur Asing, termasuk jama'ah Haji, menu yang diberikan adalah air minum, nasi, ikan asin 0,25 kg, kopi 0,03 kg, teh 0,02 $\mathrm{kg}$, gula pasir $0,1 \mathrm{~kg}$ dan lauk pauk seperti daging, sambal, dan garam diberikan cukup untuk satu hari.

2. Kesehatan

Untuk dapat naik kapal, jama'ah harus diperiksa oleh mantri kesehatan dengan teliti guna menanggulangi penyakit menular.

3. Nilai Uang

Nakhoda atau administrator kapal ditunjuk khusus untuk menerima titipan uang dan barang berharga milik jama'ah untuk mengurangi hal yang tidak diinginkan. Para jama'ah juga akan mendapat perlakuan baik dari nakhoda.

4. Meninggal

Diberikan tindakan cepat kepada agen di Jeddah atau Batavia, paspor dan tiketnya diberikan kepada agen. Dan kematiannya dicatat secara resmi.

\section{Pemerasan Uang}

Nakhoda mengawasi penumpang dan awak kapalnya agar tidak terjadi pelanggaran. Setiap yang melanggar akan mendapat hukuman keras.

Dengan adanya perbedaan fasilitas yang bisa dipilih dari tiap-tiap maskapai perjalanan oleh para calon jama'ah, yang berarti semakin banyak pilihan bagi calon jama'ah, hal ini menjadikan persaingan antar perusahaan juga semakin ketat. Oleh karena itu, perusahaan-perusahaan tersebut juga melakukan sosialisasi langsung terjun ke tengah masyarakat melalui agen-agen yang dimiliki. Banyak di antara agen itu yang menggandeng tokoh-tokoh agama ataupun pejabat di daerah untuk memobilisasi jama'ah pada perusahaan tertentu, salah satunya adalah praktek yang dilakukan oleh agen Herklots dengan wedana Cilegon, Entol Goena Djaja.Sebagai imbalan pada wedana Cilegon yang telah memobilisasi jama'ah haji dari Cilegon untuk menggunakan 
maskapainya, Herklots memberikan tiket gratis untuk mertua dan anak wedana.24

Tingkat persaingan antar perusahaan yang sangat ketat tersebut tidak mengherankan,mengingat industri pelayanan transportasi jama'ah haji memang membawa potensi keuntungan ekonomis yang cukup besar. Sebagai catatan, sesuai aturan pemerintah kolonial, anggaran minimaltiap jama'ah haji pada tahun 1890-an adalah 400-500 gulden.25 Anggaran tersebut termasuk harga tiket pulang pergi (retourbiljet) yang diterapkan oleh perusahaan, dengan nominal tergantung pada kapal yang digunakan. Sebagai ilustrasi, kapal milik Nederland dan Rotterdamsche ada yang dijual seharga 95 gulden (pergi-pulang) dan ada juga yang 150 gulden atau 180 gulden. Di perusahaan lain, ada yang menjual tiket dengan harga sangat murah. Untuk kapal berbendera Perancis, rute Singapura-Jeddah hanya sekitar 7-10 gulden. Namun secara resmi, standar harga tiket adalah 110 gulden.26Dengan rata-rata biaya tiket kapal sebesar 110 gulden, dapat dipastikan besarnya keuntungan yang bisa diraih oleh perusahaan jika dalam satu kapal bisa memuat rata-rata 2000 penumpang.

Potensi keuntungan yang bisa diraih perusahaan pelayaran ini juga dapatsemakin besar jika bekerjasama dengan syekh yang biasa menjadi guide atau pemandu bagi jama'ah dari Indonesia di Tanah Suci. Sebagaimana diketahui, di Tanah Suci ada ratusan orang syekhyang bekerja secara mandiri ataupun bergabung dengan perusahaan tertentu.27 Keuntungan yang bisa diraih oleh syekh ini juga cukup besar, mulai dari komisi standar 17 gulden hingga mencapai 160 gulden dari tiap jama'ah yang didampinginya.28

\footnotetext{
25 Dien, Berhaji, h. 134.

Dien, Berhaji, h. 104. Lihat juga dalam surat Snouck Hurgronje kepada Gubernur Jenderal Hindia Belanda bertanggal Betawi, 20 Juni 1889. E. Gobee, Nasihat-Nasihat C. Snouck Hurgronje, h. 1397-1400

Keberadaan syekh sebagai pemandu jama'ah dari Indonesia ini merupakan fenomena yang menarik, karena mereka menjalankan tugas dan tanggungjawab yang besar untuk mengatur segala keperluan jama'ah di negeri asing. Dalam satu musim haji, tiap syekh bisa melayani hingga rata-rata 50 orang jama'ah. Dien, Berhaji, h. 61
} 
Dengan kerjasama maskapai pengangkutan dengan syekhbedrijf, keuntungan yang bisa didapat juga menjadi semakin besar. Apalagi selain menjadi pemandu, para syekhini juga menyediakan jasa peminjaman uang untuk jama'ah. Peminjaman tersebut bisa terjadi,karena kebanyakan jama'ah tidak membawa cukup banyak uang atau emas/perak dengan alasan keamanan dan sebagainya. Oleh karena itu, mereka merasa perlu untuk meminjam kepada para syekhtersebut selama di Tanah Suci dan akan mengembalikannya setelah tiba kembali di Indonesia. Adapun peminjaman itu berbunga sangat besar, berkisarantara $50-100 \% .29$

Namun demikian, di tengah kepungan pengusaha-pengusaha yang agresif mengeruk keuntungan tersebut, jama'ah haji tidak bisa berbuat apa-apa sehingga para pengusaha semakin giat mencari calon jama'ah. Hingga akhirnya pada akhir abad 19 dan awal 1900-an, skandal perusahaan yang di antaranya melibatkan agen Herklots dan maskapai Assegaff secara terpisah mulai terbongkar. Pemerintah kolonial menemukan kelicikan Herklots dan Assegaff dalam mengeruk keuntungan dengan menipu para jama'ah haji, mulai dari pembantaran di Singapura, penggunaan kapal yang tidak laik untuk penumpang, hingga perbudakan di perkebunan di Malaysia dengan dalih untuk membayar hutang.30

Setelah peristiwa tersebut, pelayanan yang diberikan oleh perusahaan perhajian secara berangsur-angsur terus ditingkatkan. Demikian juga regulasi yang dikeluarkan oleh pemerintah kolonial akhirnya diterbitkan, Ordonansi 1922, semakin memperhatikan keselamatan dan kenyamanan jama'ah haji selama penyelenggaraan ibadah suci tersebut.

\section{Penutup}

Dinamika ibadah haji dari Indonesia di masa kolonial memang memiliki cerita yang sangat panjang dan menarik. Dari aspek perjalanannya saja sudah tergambar bagaimana beratnya perjalanan yang harus ditempuh para jama'ah, mulai dari lamanya waktu tempuh karena keberadaan moda transportasi kapal yang masih sederhana, hingga rintangan yang dihadapi, baik berupa tantangan alam maupun 
resiko keamanan. Kemudian pada masa tersebut, juga diperoleh potret yang menarik mengenai menjamurnya perusahaan-perusahaan penyedia jasa layanan perjalanan ibadah haji. Dan seiring dengan makin ramainya jama'ah haji dari Indonesia, pemerintah kolonial pun membuat beragam regulasi yang mengatur tertibnya pelaksanaan ibadah tahunan umat Islam tersebut. Dari sedikit potret yang dapat diambil dari perjalanan haji di masa kolonial tersebut, ibrah tentunya diharapkan dapat diambil untuk bahan refleksi perjalanan ibadah haji di masa depan.

\section{Bibliografi}

Aplikasi web-based www.distancefromto.net, diakses pada 1 September 2016

Arsip Nasional RI, Besluit 1 Juni 1896 no. 6

Arsip Nasional RI, Mgs. 4-11-1893 no. 2811, G.B. Agenda 2280/1895

Arsip Nasional RI, TGs tanggal November 1896 No. 353 Geh.

C. Snouck Hurgronje, Kumpulan Karangan Snouck Hurgronje IX (Jakarta:

INIS, 1994)

E. Gobee dan C. Adriaanse, Nasihat-Nasihat C. Snouck Hurgronje semasa Kepegawaiannya Kepada Pemerintah Hindia Belanda 1889-1936 Seri VIII (Jakarta: INIS, 1993)

J. Eisenberger, Indie en de Bedevaart naar Mekka (Leiden: M. Dubbeldeman, 1928)

Martin van Bruinessen, Kitab Kuning Pesantren dan Tarekat Tradisi-Tradisi Islam di Indonesia (Bandung: Mizan, 1995)

M. Dien Majid, Berhaji di Masa Kolonial (Jakarta: CV. Sejahtera, 2008)

M. Shaleh Putuhena, Historiografi Haji Indonesia (Yogyakarta: LKiS, 2007) 
